\title{
PRKG2 wt Allele
}

National Cancer Institute

\section{Source}

National Cancer Institute. PRKG2 wt Allele. NCI Thesaurus. Code C51173.

Human PRKG2 wild-type allele is located in the vicinity of 4q13.1-q21.1 and is approximately $116 \mathrm{~kb}$ in length. This allele, which encodes cGMP-dependent protein kinase 2 protein, is involved in cGMP-dependent signaling which regulates cellular processes such as cytoskeletal organization and cell motility. The PRKG2 gene is associated with long-term depression. 